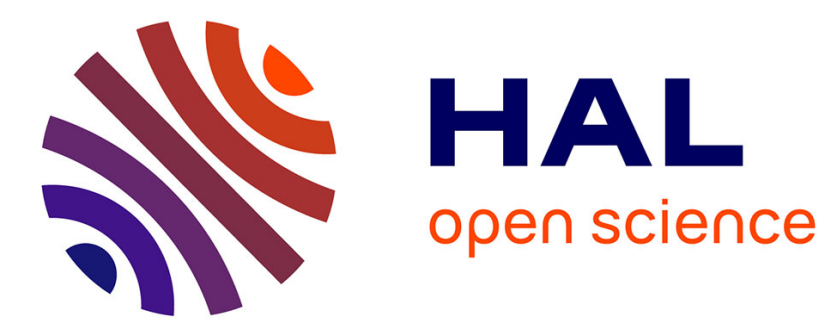

\title{
An antibacterial and antifungal phenylpropanoid from Carum montanum (Coss. et Dur.) Benth. et Hook.
}

\author{
Hocine Laouer, Meriem El Kolli, Soizic Prado, Nicolas Baldovini
}

\section{To cite this version:}

Hocine Laouer, Meriem El Kolli, Soizic Prado, Nicolas Baldovini. An antibacterial and antifungal phenylpropanoid from Carum montanum (Coss. et Dur.) Benth. et Hook.. Phytotherapy Research, 2009, 23 (12), pp.1726-n/a. 10.1002/ptr.2820 . hal-00477801

\section{HAL Id: hal-00477801 \\ https://hal.science/hal-00477801}

Submitted on 30 Apr 2010

HAL is a multi-disciplinary open access archive for the deposit and dissemination of scientific research documents, whether they are published or not. The documents may come from teaching and research institutions in France or abroad, or from public or private research centers.
L'archive ouverte pluridisciplinaire HAL, est destinée au dépôt et à la diffusion de documents scientifiques de niveau recherche, publiés ou non, émanant des établissements d'enseignement et de recherche français ou étrangers, des laboratoires publics ou privés. 


\section{An antibacterial and antifungal phenylpropanoid from Carum montanum (Coss. et Dur.) Benth. et Hook.}

\begin{tabular}{|c|c|}
\hline Journal: & Phytotherapy Research \\
\hline Manuscript ID: & PTR-08-0896.R1 \\
\hline Wiley - Manuscript type: & Full Paper \\
\hline $\begin{array}{r}\text { Date Submitted by the } \\
\text { Author: }\end{array}$ & 13-Feb-2009 \\
\hline Complete List of Authors: & $\begin{array}{l}\text { Laouer, Hocine; University of Setif, Biology } \\
\text { El Kolli, Meriem; University of Setif, Biology } \\
\text { Prado, Soizic; Muséum National d'Histoire Naturelle } \\
\text { Baldovini, Nicolas; Université de Nice-Sophia Antipolis, Chemistry }\end{array}$ \\
\hline Keyword: & $\begin{array}{l}\text { Carum montanum, nothoapiole, phenylpropanoids, antibacterial } \\
\text { activity, antifungal activity, apiaceae }\end{array}$ \\
\hline
\end{tabular}

\section{\$) ScholaronE" \\ Manuscript Central}




\title{
An antibacterial and antifungal phenylpropanoid from
}

\section{Carum montanum (Coss. et Dur.) Benth. et Hook.}

\author{
Hocine Laouer ${ }^{1}$, El Kolli Meriem ${ }^{1}$, Soizic Prado ${ }^{2}$, and Nicolas Baldovini ${ }^{3{ }^{3} *}$ \\ ${ }^{1}$ Department of Biology, University of Setif, Mabouda, 19000, Setif, Algeria \\ ${ }^{2}$ Laboratoire de Chimie et Biochimie des Substances Naturelles - UMR 5154 CNRS, Muséum National \\ d'Histoire Naturelle, 63 rue Buffon, 75005 Paris, France. \\ ${ }^{3}$ Université de Nice Sophia-Antipolis, Laboratoire de Chimie des Molécules Bioactives et des Arômes, \\ CNRS UMR 6001, Parc Valrose, F-06108 Nice cedex 2, France.
}

The volatile constituents of the aerial parts of Carum montanum (Coss. et Dur.) Benth. et Hook. were analysed by GC-FID and GC-MS, and the main component was isolated and identified as nothoapiole. The antibacterial and antifungal activities of this compound and of the total oil were investigated against Gram negative (P. aeruginosa, E. coli), Gram positive (E. faecalis, S. aureus, S. epidermitis, S. saprophyticus, $S$. simulans, S. lugdunensis) bacteria and on one strain of fungus (C. tropicalis).

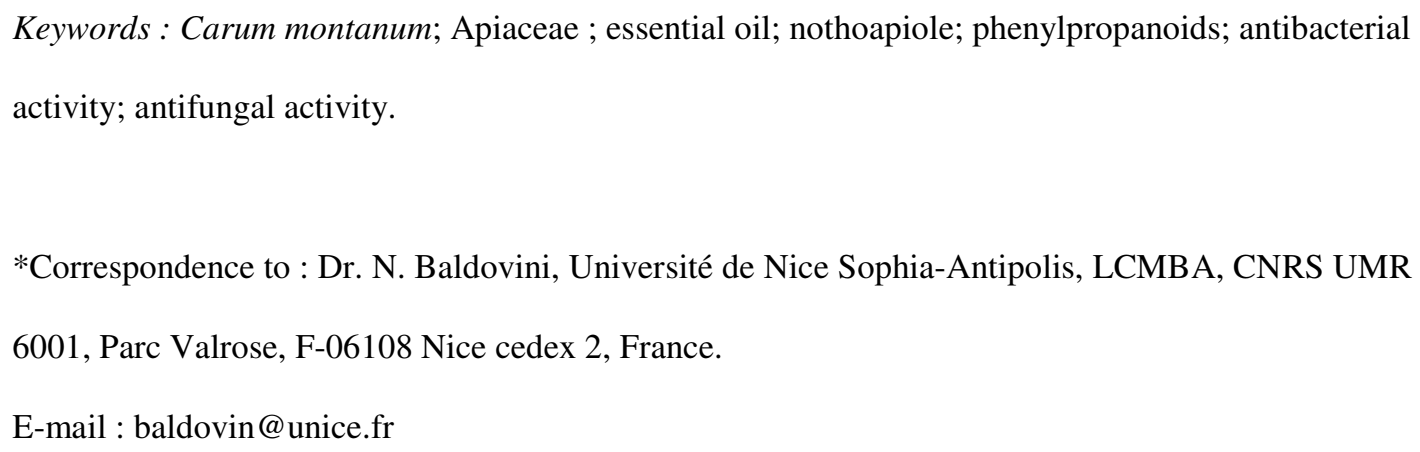




\section{INTRODUCTION}

Caraway (Carum carvi L.) is one of the oldest spices cultivated in Europe. The fruit of caraway is a schizocarp, which at harvest splits into two halves, erroneously called "seeds", which are used in the flavouring of bread (e.g., rye bread), cheeses, sauerkraut, candies, meat products, sauces and alcoholic liqueurs, such as the German Kummel. It is also a source of carvone for cosmetics, toothpaste, chewing gum and pharmaceutical preparations. The seeds have been used in alternative medicine for the treatment of colics, loss of appetite and digestive disorders as well as to dispel worms. Antipasmodic, emmenagogue, expectorant, galactogogue, stimulant, stomachic and tonic properties have also been reported (de Carvalho and da Fonseca, 2005).

While Carum carvi L. is the best known member of the Carum genus (Apiaceae), several other species have been investigated regarding their chemical composition and biological properties, especially C. copticum (Boskabady et al., 2003; DashtiRahmatabadi et al., 2007; Sahaf et al., 2007) and to a lesser extent Carum nigrum (Singh et al., 2006).

In the course of our studies of the pharmacological properties of endemic plants from Algeria, we investigated the phytochemistry of a little-known species of the Carum genus: C. montanum (Coss. et Dur.) Benth. et Hook. [syn. Selinopsis montana Coss. et Dur.], which is one of the two endemic Carum species described in Algeria (Quezel and Santa, 1963), the other one beeing C. foetidum (Coss. et Dur.) Benth. et Hook. syn. Selinopsis foetida Coss. et Dur. C. montanum grows wild in calcareous mountainous regions, such as the Constantine Saharian and Tell Atlas, as well as in the Kabyle and 


\section{MATERIAL AND METHODS}

Plant material. Fully flowered aerial parts of Carum montanum (Coss. et Dur.) Benth. et Hook. were collected in Megress Mountain, at $1500 \mathrm{~m}$ above sea level, during May 2006. A voucher specimen (B-6306) has been deposited in the Muséum d'Histoire Naturelle de la Ville de Nice, France.

Extraction of volatiles and isolation of nothoapiole. Essential oil was obtained by hydrodistillation of dried aerial parts $(1.2 \mathrm{ml} / \mathrm{kg}: 1.1 \%$ yield $)$ or roots $(0.8 \mathrm{ml} / \mathrm{kg}: 0.7 \%$ yield) using a Clevenger type apparatus, and was dried over anhydrous sodium sulfate. Pure nothoapiole was obtained by several successive column chromatographies on silica gel using petroleum ether/diethyl ether gradients for elution. 
General. The NMR spectra were recorded on a Bruker WM 200 or $500 \mathrm{MHz}$ spectrometer in $\mathrm{CDCl}_{3}$. The chemical shift values are reported with reference to TMS and the coupling constants are given in Hz. GC and GC-MS analyses were carried out using an Agilent 6890N gas chromatograph apparatus equipped with a flame ionization detector (FID) and coupled to a quadrupole Agilent 5973 network mass selective detector working in electron impact (EI) mode at $70 \mathrm{eV}$ (scanning over 35-350 amu range). The gas chromatograph was equipped with two fused silica capillary columns HP-1 (PDMS, $50 \mathrm{~m} \times 0.2 \mathrm{~mm}$ i.d., film thickness : $0.33 \mu \mathrm{m})$. The analytical parameters (identical for GC and GC-MS analyses unless specified) were the following: The carrier gas was helium at a flow rate of $1 \mathrm{~mL} / \mathrm{min}$. The oven temperature was programmed from 60 to $250^{\circ} \mathrm{C}$ at $2^{\circ} \mathrm{C} / \mathrm{min}$ and held isothermal for $40 \mathrm{~min}$. The injector (split mode, ratio $1 / 100$ ) temperature was $250^{\circ} \mathrm{C}$. The FID temperature was set at $250^{\circ} \mathrm{C}$, and in the GC-MS analyses, the temperatures of the ion source and transfer line were 170 and $280^{\circ} \mathrm{C}$, respectively. The constituents of the essential oil were identified by comparison of their mass spectral pattern and retention indices (RI) with those of pure compounds registered in commercial libraries and literature data (McLafferty and Staufer, 1989; BACIS, 1999; Joulain and König, 1999; NIST, 1999) and with a laboratory-made database built from authentic compounds.

Bacterial strains and cultures conditions. References strains of Staphylococcus aureus subsp. aureus (ATCC 6538), Staphylococcus epidermitis (CIP 10464), Staphylococcus saprophyticus subsp. Saprophyticus (CIP 10464), Staphylococcus simulans (CIP 81.64), Staphylococcus lugdunensis (CIP 103584) were obtained from the Collection of the Institut Pasteur, Paris, France. Enterococcus faecalis (14C1104) 
and Pseudomonas aeruginosa (13C3104) strains were isolated from patients and kindly provided by Laurent Marsollier (Institut Pasteur). Escherichia coli (ATCC 9738) and Candida tropicalis (ATCC 66029) were from the National Museum of Natural History (NMNH). Bacteria species were cultivated for 24 hrs in Mueller Huntington's medium $(\mathrm{MH})$ at $37^{\circ} \mathrm{C}$ and for $48 \mathrm{hrs}$ at $30^{\circ} \mathrm{C}$ in Sabouraud dextrose medium (Sanofi Diagnostic Pasteur) for C. tropicalis.

Disc diffusion assay. The antibacterial activity of the essential oil was evaluated using the standardized filter paper disk (6 mm non impregnated disk. Antibiotica assay discs, Grade 2668 Schleider and Schuell) diffusion method according to the Kirby-Bauer method (Bauer et al., 1966). Briefly, culture suspension of the tested microorganisms (approximately $10^{6} \mathrm{CFU} / \mathrm{mL}$ ) was spread on the solid media plates $(50 \mathrm{~mL})$. Filter paper discs were impregnated with $10 \mu \mathrm{L}$ of serial dilutions in dimethylsulfoxide (DMSO, Sigma) of the essential oil and placed onto the solid media plates. The diameter of inhibition was measured after 24 or $48 \mathrm{~h}$ of incubation at $30^{\circ} \mathrm{C}$ or $37^{\circ} \mathrm{C}$. Ampicillin (Sigma) and DMSO were used as positive and negative controls, respectively.

\section{RESULTS AND DISCUSSION}

Our preliminary investigation of the GC-MS profile of the aerial part essential oil showed a main $(62.8 \%)$ unidentified constituent, together with common monoterpenes and sesquiterpenes (table 1). By successive preparative column chromatographies on silica gel, this component was isolated in pure form and identified as nothoapiole (1) by MS and NMR analysis, and comparison with spectral data reported in the literature 
(Rahman et al., 1999). This highly oxygenated phenylpropanoid is structurally related to myristicin (2), apiole (3) and dill-apiole (4) which are widespread in many vegetal species, but $\mathbf{1}$ is actually much less common than these compounds: Up to now, $\mathbf{1}$ was identified in Carum nigrum essential oil and oleoresin (Singh et al., 2006) as well as in five other vegetal species : Perilla frutescens (Ito et al., 1999), Pimpinella serbica (Ivanic et al., 1983), Molopospermum peloponnesiacum (Kubeczka and Ullmann, 1983), Peucedanum pauciradiatum (Bagirov et al., 1982) and Nothosmyrnium japonicum (Saiki et al., 1970) and in the brown alga Spatoglossum variabile (Rahman et al., 1999). However, none of these sources contained such a high percentage of nothoapiole as in C. montanum. Moreover, although the ${ }^{1} \mathrm{H}$ NMR spectrum of this compound was described several times (Saiki et al., 1970; Bagirov et al., 1982; Rahman et al., 1999), the ${ }^{13} \mathrm{C}$ NMR data with the assignments have never been reported yet, hence these informations were deduced from a series of $1 \mathrm{D}$ and 2D NMR experiments including COSY, NOESY, HSQC and HMBC, and are summarised in table 2.

Interestingly, myristicin (2), apiole (3) and dillapiole (4) were also identified in the essential oil of the aerial parts of C. montanum, as well as in the essential oil of the roots which consisted almost exclusively in a mixture of $\mathbf{1}$ and $\mathbf{4}$ (78\% and 9\%, respectively). Their co-occurence is not surprising since Ito et al. (1999) showed that in Perilla frutescens, nothoapiole is biosynthetised by successive enzymatic methoxylations of myristicin, the biogenetic pathway beeing the following $: \mathbf{2} \rightarrow \mathbf{4} \rightarrow \mathbf{1}$. The phenylpropanoids family is rich in biologically active compounds. Myristicin 2 was shown to be insecticide (Lichtenstein and Casida, 1963; Lichtenstein et al., 1974; Berenbaum and Neal, 1985) and to synergize the activity of synthetic insecticides 
(Lichtenstein et al., 1974; Berenbaum and Neal, 1985). Many other interesting properties of $\mathbf{2}$ were described, such as hepatoprotective (Morita et al., 2003), antiinflammatory (Ozaki et al., 1989) and CNS depressant (Shin et al., 1988). Several studies reported also that this compound could be a potential chemopreventive compound (Zheng et al., 1992; Ahmad et al., 1997). Apiole (3) was less studied, but nevertheless showed also a wealth of biological activities, such as antifungal (Meepagala et al., 2005; Razzaghi-Abyaneh et al., 2007), antioxydant (Zhang et al., 2006), phytotoxic (Meepagala et al., 2005) and an even more potent synergistic insecticide potential than 2 (Lichtenstein et al., 1974). In fact, in most of the studies where $\mathbf{2}$ and $\mathbf{3}$ or $\mathbf{4}$ were compared regarding their biological activities, $\mathbf{3}$ and $\mathbf{4}$ were more potent than 2 (Lichtenstein et al., 1974; Zhang et al., 2006; Razzaghi-Abyaneh et al., 2007), while unwanted carcinogenic and genotoxic properties (well established for safrole and estragole) decreased with further methoxylations of the aromatic nucleus in the order : safrole $>\mathbf{2}>\mathbf{3}>\mathbf{4}$ (Zhou et al., 2007).

Only one study explored recently the biological activity of a nothoapiole containing mixture through the evaluation of the antioxydant, antibacterial and antifungal properties of Carum nigrum essential oil and oleoresin (Singh et al., 2006), but this substance was contained in low percentage in these mixtures and was not evaluated alone. The apparent pharmacological potential of the highly oxygenated phenylpropanoids prompted us to better define the biological potential of $\mathbf{1}$, of which $C$. montanum could be an interesting source. 
As shown in table 3 , the essential oil of $C$. montanum was devoid of significant antimicrobial activity against the Gram - bacteria tested. The essential oil and its half dilution present a weak activity (respectively 6 and $5 \mathrm{~mm}$ ) against $E$. coli compared to ampicillin control $(12 \mathrm{~mm})$. Strains of $P$. aeruginosa were particulary resistant, even to $10 \mu \mathrm{l}$ of the essential oil, the highest quantity used in this assay. Nevertheless, a more potent effect on Gram + was obtained. We observed inhibition of the crude extract and its half dilutions on $S$. aureus with diameters of inhibition from 11 to $6 \mathrm{~mm}$. Surprisingly, dilutions of the essential oil did not affect the activity as the diameters of inhibition are relatively constant. In contrast, no activity was observed on E. faecalis. These observations lead us to investigate others pathogenic strains from Staphylococcus genus such as $S$. epidermitis, $S$. saprophiticus, $S$. simulans, $S$. lugdunensis. The level of antibacterial activity was relatively high and constant at all the concentrations used except on S. saprophyticus which turned out to be totally resistant to the essential oil. As seen on Table 3, the most sensitive strain is $S$. simulans with a diameter of inhibition for the crude extract of $28 \mathrm{~mm}$. This is relatively close from the one obtained for $30 \mu \mathrm{g}$ of ampicillin. No significant difference of activity was observed for half dilution, but a loss of activity was measured for the following dilutions. Good activity was also noted on $S$. lugdunensis with a $12 \mathrm{~mm}$ diameter of inhibition for the highest concentration tested. This diameter is actually more important than the $9 \mathrm{~mm}$ observed for $30 \mu \mathrm{g}$ of ampicillin. A related range of activity on fungus $C$. tropicalis was observed with a diameter of inhibition around $15 \mathrm{~mm}$ at the highest concentration. The lack of effect of ampicillin on Candida growth is consistent with this antibacterial agent. 
In a second step, we also evaluated the antibacterial activity of pure nothoapiole (1). As observed for the total extract, 1 did not inhibit E. coli growth. Moreover, as for the essential oil, a strong antibacterial activity was measured on Staphylococcus genus. As shown in table 3, $10 \mu$ l of nothoapiole inhibited the growth of $S$. epidermitis and $S$. simulans with a $8 \mathrm{~mm}$ diameter of inhibition. Interestingly, this activity, although significant, is actually lower than that of the total essential oil. On the other hand, the inhibition on S. lugdunensis and C. tropicalis was close to the level of effect exhibited by the essential oil.

In conclusion, the essential oil of Carum montanum displayed a good activity against Gram + bacteria, particularly against Staphylococcus strains. The results against fungus C. tropicalis are also of interest and further studies on other fungi strains will help in the evaluation of the therapeutic potential of this essential oil. The nothoapiole inhibition of Staphylococcus strains growth we observed pointed out the contribution of this component to the antibacterial activity of the entire essential oil. In the case of the activity on $C$. tropicalis, the related level of activities observed suggest that nothoapiole is the main compound causing the antifungal effect of $C$. montanum essential oil.

\section{Acknowledgements}

HL thanks "La ville de Paris" for a scholarship. 


\section{REFERENCES}

Ahmad H, Tijerina MT, Tobola AS. 1997. Preferential overexpression of a class MU glutathione S-transferase subunit in mouse liver by myristicin. Biochem Biophys Res Commun 236: 825-828.

BACIS. 1999. (Boelens Aroma Chemical Information Service) ESO 2000, The Complete Database of Essential Oils. Huizen, The Netherlands.

Bagirov VY, Belyi MB, Rasulov FA, Ismailov NM. 1982. Aromatic compounds of Peucedanum pauciradiatum. Khimiya Prirodnykh Soedinenii 1: 127-129.

Bauer AW, Kirby WM, Sherris JC, Turck M. 1966. Antibiotic susceptibility testing by a standardized single disk method. Am J Clin Pathol 45: 493-496.

Benahmed M, Akkal S, Louaar S, Laouer H, Duddeck H. 2006. A new furanocoumarin glycoside from Carum montanum (Apiaceae). Biochem Syst Ecol 34: 645-647.

Berenbaum M, Neal JJ. 1985. Synergism between myristicin and xanthotoxin, a naturally cooccurring plant toxicant. J Chem Ecol 11: 1349-1358.

Boskabady MH, Ramazani M, Tabei T. 2003. Relaxant effects of different fractions of essential oil from Carum copticum on guinea pig tracheal chains. Phytother Res 17: 1145-1149.

Dashti-Rahmatabadi MH, Hejazian SH, Morshedi A, Rafati A. 2007. The analgesic effect of Carum copticum extract and morphine on phasic pain in mice. $J$ Ethnopharmacol 109: 226-228.

de Carvalho CCCR, da Fonseca MMR. 2005. Carvone: Why and how should one bother to produce this terpene. Food Chem 95: 413-422.

Ito M, Toyoda M, Yuba A, Honda G. 1999. Genetic analysis of nothoapiol formation in Perilla frutescens. Biol Pharm Bull 22: 598-601.

Ivanic R, Savin K, Robinson FV. 1983. Essential oil from Pimpinella serbica fruits. Planta Med. 48: 60-61.

Joulain D, König WA. 1999. The Atlas of Spectral Data of Sesquiterpene Hydrocarbons: Hamburg, Germany E. B.-Verlag.

Kubeczka KH, Ullmann I. 1983. Essential oils of Apiaceae (Umbelliferae). 9. Chemotypes of Molopospermum peloponnesiacum (L.) Koch. Zeitschrift fuer Naturforschung, C: Journal of Biosciences 38C: 189-193.

Lichtenstein EP, Casida JE. 1963. Myristicin, an insecticide and synergist occurring naturally in the edible parts of parsnips. J Agric Food Chem 11: 410-415.

Lichtenstein EP, Liang TT, Schulz KR, Schnoes HK, Carter GT. 1974. Insecticidal and synergistic components isolated from dill plants. J Agric Food Chem 22: 658664.

McLafferty FW, Staufer DB. 1989. The Wiley NBS Registry of Mass Spectral Data: New York Wiley.

Meepagala KM, Sturtz G, Wedge DE, Schrader KK, Duke SO. 2005. Phytotoxic and antifungal compounds from two Apiaceae species, Lomatium californicum and Ligusticum hultenii, rich sources of Z-ligustilide and apiol, respectively. J Chem Ecol 31: 1567-1578.

Morita T, Jinno K, Kawagishi H, Arimoto Y, Suganuma H, Inakuma T, Sugiyama K. 2003. Hepatoprotective Effect of Myristicin from Nutmeg (Myristica fragrans) 
on Lipopolysaccharide/D-Galactosamine-Induced Liver Injury. J Agric Food Chem 51: 1560-1565.

NIST. 1999. National Institute of Standards and Technology NISTEPAWIH Mass Spectral Library, 1.7. 1.7

Ozaki Y, Soedigdo S, Wattimena YR, Suganda AG. 1989. Antiinflammatory effect of mace, aril of Myristica fragrans Houtt., and its active principles. Jpn J Pharmacol 49: 155-163.

Quezel P, Santa S. 1963. Nouvelle flore de l'Algérie et des régions désertiques méridionales. Editions du Centre National de la Recherche Scientifique: Paris, France.

Rahman A, Choudhary MI, Hayat S, Khan AM, Ahmad A, Malik S. 1999. Spatozoate and varninasterol from the brown alga Spatoglossum variabile. Phytochemistry 52: 495-499.

Razzaghi-Abyaneh M, Yoshinari T, Shams-Ghahfarokhi M, Rezaee M-B, Nagasawa H, Sakuda S. 2007. Dillapiol and apiol as specific inhibitors of the biosynthesis of aflatoxin G1 in Aspergillus parasiticus. Biosci Biotechnol Biochem 71: 23292332.

Sahaf BZ, Moharramipour S, Meshkatalsadat MH. 2007. Chemical constituents and fumigant toxicity of essential oil from Carum copticum against two stored product beetles. Insect Science 14: 213-218.

Saiki Y, Okamoto M, Ueno A, Uchida M, Fukushima S. 1970. Gas-chromatographic studies on natural volatile oils. VIII. Essential oils of Chinese medicines "Gaoben". Yakugaku Zasshi 90: 344-351.

Shin KH, Kim ON, Woo WS. 1988. Studies on crude drugs acting on drug-metabolizing enzymes. Part 12. Isolation of hepatic drug metabolism inhibitors from the seeds of Myristica fragrans. Arch Pharm Res 11: 240-243.

Singh G, Marimuthu P, De Heluani CS, Catalan CAN. 2006. Antioxidant and biocidal activities of Carum nigrum (seed) essential oil, oleoresin, and their selected components. J Agric Food Chem 54: 174-181.

Zhang H, Chen F, Wang X, Yao H-Y. 2006. Evaluation of antioxidant activity of parsley (Petroselinum crispum) essential oil and identification of its antioxidant constituents. Food Res Int 39: 833-839.

Zheng GQ, Kenney PM, Lam LKT. 1992. Myristicin: A potential cancer chemopreventive agent from parsley leaf oil. J Agric Food Chem 40: 107-110.

Zhou G-D, Moorthy B, Bi J, Donnelly KC, Randerath K. 2007. DNA adducts from alkoxyallylbenzene herb and spice constituents in cultured human (HepG2) cells. Environ Mol Mutagen 48: 715-721. 
<smiles>C=CCc1c(OC)c(OC)c2c(c1OC)OCO2</smiles>

1<smiles>C=CCc1cc2c(c(OC)c1OC)OCO2</smiles><smiles>C=CCc1cc(OC)c2c(c1)OCO2</smiles>

$\underline{2}$<smiles>C=CCc1cc(OC)c2c(c1OC)OCO2</smiles>

Figure 1. Structure of nothoapiole (1) and of selected oxygenated phenylpropanoids. 
Table 1. Composition of the essential oil of Carum montanum.

\begin{tabular}{ccl}
\hline $\mathbf{R I}^{\mathbf{a}}$ & $\boldsymbol{\%}^{\mathbf{b}}$ & \\
\hline 772 & $\mathrm{t}$ & hexanal \\
823 & 0.6 & E-hex-2-enal \\
833 & 0.1 & Z-hex-3-enol \\
875 & $\mathrm{t}$ & heptanal \\
923 & 0.1 & $\alpha$-thujene \\
930 & 0.9 & $\alpha$-pinene \\
964 & 0.2 & sabinene \\
969 & 0.1 & $\beta$-pinene \\
981 & 0.9 & myrcene \\
1009 & 0.1 & $\alpha$-terpinene \\
1011 & 0.3 & para-cymene \\
1020 & 0.6 & limonene \\
1026 & 0.2 & $Z$ - $\beta$-ocimene \\
1037 & 0.7 & E- $\beta$-ocimene \\
1048 & 0.8 & $\gamma$-terpinene \\
1078 & 0.2 & terpinolene \\
1081 & $\mathrm{t}$ & nonanal \\
1100 & 0.1 & undecane \\
1136 & $\mathrm{t}$ & terpinen-4-ol \\
1224 & $\mathrm{t}$ & methyl thymyl ether \\
1266 & 0.9 & thymol \\
1275 & $\mathrm{t}$ & carvacrol \\
1300 & 0.1 & tridecane \\
1374 & 0.1 & $\alpha$-copaene \\
1379 & 0.5 & $\beta$-bourbonene \\
1385 & 0.2 & $\beta$-elemene \\
1413 & 2.5 & $\beta$-caryophyllene \\
1430 & 0.8 & $\alpha$-bergamotene \\
1446 & 7.1 & $\alpha$-humulene \\
1468 & 0.4 & ylangene \\
1471 & 2.2 & germacrene-D \\
1483 & 0.4 & myristicin \\
1486 & 0.2 & $\alpha$-selinene \\
1490 & 0.1 & $\alpha$-muurolene \\
1495 & 0.5 & $\alpha$-farnesene \\
1499 & 0.1 & $\alpha$-bisabolene \\
1512 & 0.6 & $\beta$-sesquiphellandrene \\
1516 & 0.2 & elemicin \\
1562 & 0.2 & $E$-caryophyllene oxide \\
1589 & 8.5 & dill apiole \\
1640 & $\mathrm{t}$ & apiole \\
1738 & 62.8 & nothoapiole \\
2069 & 0.1 & osthole \\
\hline
\end{tabular}

${ }^{a}$ Retention indices on HP-1 column relative to C7-C22 n-alkanes.

${ }^{\mathrm{b}}$ Area FID. $\mathrm{t}$ : trace compound $(<0.1 \%)$. 
Table 2. ${ }^{1} \mathrm{H}$ NMR, ${ }^{13} \mathrm{C}$ NMR and HMBC data of nothoapiole (1).

\begin{tabular}{ccccc}
\hline Atom no. & $\boldsymbol{\delta}^{\mathbf{1}} \mathbf{H}$ & $\begin{array}{c}\text { multiplicity } \\
(\boldsymbol{J} \text { in Hz })\end{array}$ & $\boldsymbol{\delta}^{\mathbf{1 3}} \mathbf{C}$ & HMBC $(\mathbf{H} \rightarrow \mathbf{C})$ \\
\hline 1 & - & - & 118.8 & - \\
2 & - & - & 145.1 & - \\
3 & - & - & $134.6^{*}$ & - \\
4 & - & - & $137.8^{*}$ & - \\
5 & - & - & 133.4 & $\mathrm{C}-2$ \\
6 & - & - & 136.7 & $\mathrm{C}-3, \mathrm{C}-4$ \\
7 & 3.77 & $\mathrm{~s}, 3 \mathrm{H}$ & 60.2 & $\mathrm{C}-5$ \\
8 & 5.90 & $\mathrm{~s}, 2 \mathrm{H}$ & 101.3 & $\mathrm{C}-6$ \\
9 & 3.94 & $\mathrm{~s}, 3 \mathrm{H}$ & 60.5 & $\mathrm{C}-1$ \\
10 & 3.89 & $\mathrm{~s}, 3 \mathrm{H}$ & 61.6 & $\mathrm{C}-11, \mathrm{C}-12$ \\
11 & 3.33 & $\mathrm{dt}(1.6 ; 6), 2 \mathrm{H}$ & 28.4 & $\mathrm{C}-1, \mathrm{C}-2, \mathrm{C}-6, \mathrm{C}-12, \mathrm{C}-13$ \\
12 & 5.95 & $\mathrm{~m}, 1 \mathrm{H}$ & 137.8 & \\
13 & 4.97 & $\mathrm{~m}, 2 \mathrm{H}$ & 114.5 &
\end{tabular}


Table 3. Antibacterial activities of $C$. montanum essential oil and nothoapiole (1)

\begin{tabular}{|c|c|c|c|c|c|c|}
\hline \multirow[b]{2}{*}{ Compounds/antibiotic tested } & \multicolumn{6}{|c|}{ Inhibition zone $(\mathrm{mm})^{\mathrm{a}}$} \\
\hline & EO & $\mathrm{EO}$ & $\mathrm{EO}$ & $\mathrm{EO}$ & 1 & $A m p^{b}$ \\
\hline Concentration of compounds in DMSO (\%) & 100 & 50 & 25 & 12.5 & 100 & $(30 \mu \mathrm{g})$ \\
\hline Amount of substance per disc $\left(\mu \mathrm{g} .10^{2}\right)$ & 90 & 45 & 22.5 & 11.25 & 90 & \\
\hline \multicolumn{7}{|l|}{ Strains } \\
\hline Escherichia coli & 6 & 5 & 0 & 0 & 0 & 12 \\
\hline Enterococcus faecalis & 0 & 0 & 0 & 0 & NT & 32 \\
\hline Pseudomonas aeruginosa & 0 & 0 & 0 & 0 & NT & 30 \\
\hline Staphylococcus. aureus sub aureus & 11 & 9 & 5 & 6 & 10 & 33 \\
\hline Staphylococcus epidermitis & 16 & 14 & 10 & 7 & 8 & 62 \\
\hline Staphyloccus saprophyticus subsp.saprophyticus & 0 & 0 & 0 & 0 & NT & 40 \\
\hline Staphylococcus simulans & 28 & 26 & 17 & 15 & 8 & 32 \\
\hline Staphylococcus lugdunensis & 12 & 6 & 0 & 0 & 9 & 9 \\
\hline Candida tropicalis & 14 & 12 & 11 & 10 & 10 & 0 \\
\hline
\end{tabular}

